\title{
Slipped Extraocular Muscle
}

National Cancer Institute

\section{Source}

National Cancer Institute. Slipped Extraocular Muscle. NCI Thesaurus. Code C118867.

Weakness of extraocular muscle function as a result of inadequate securing of the muscle to the sclera during strabismus surgery. 